\title{
Landslide Hazard Zonation along the MH SH-73 at Kelghar Ghat, Satara, Maharashtra
}

\author{
Subhash Vishnu Karande
}

Assistant Professor, Dept. of Geography, Chhatrapati Shivaji College, Satara, Maharashtra, India

\begin{abstract}
Road transportation is the most common victim of landslide in the world. The present study investigates the landslide hazard zonation along the MH SH-73 at Kelghar ghat between Medha and Mahabaleshwar hill station of Maharashtra. Remote Sensing and GIS were used for the landslide hazard zonation of this section. The ghat section was buffered $100 \mathrm{~m}$ on both sides to define the extent of study area based on the field investigation. The study incorporated predefined important landslide causative factors, viz. slope, rainfall, relief, lithology, soil depth, soil erosion, soil texture, land use / land cover, drainage distance, drainage density, lineament distance, lineament density, aspect, temperature, landslide inventory and in this approach fifteen thematic layers were prepared in GIS platform. The weight and score were assigned to each thematic layer based on heuristic approach on their relative importance in causing landslide. Multi-criteria model in ArcGIS 10.5 software were used for the mapping landslide hazard zones and it were classified into six zones: very high $(1.3 \%)$, high $(1.7 \%)$, moderate $(3.4 \%)$, low $(7.6 \%)$ very low $(8.4 \%)$ and no risk zone $(77.7 \%)$. The final result of this research can help for proper mitigation and adaptation measures for engineers, planners and administrators for this ghat section.
\end{abstract}

Keywords: GIS, Landslide Hazard Zonation, Remote Sensing, Susceptibility, Sahyadri, Kelghar

\section{INTRODUCTION}

Landslide is a most common natural hazard which damage lives and property ${ }^{[2]}$. Unstable ground slope due to the natural movements and anthropogenic activities are major reason of landslides. Road construction along the mountain region is frequently increases the occurrence of landslides ${ }^{[7,8,10]}$. Every year frequent closure of the road and several people have lost their lives in the ghat section due to the landslides. Landslide on the road occurs mainly due to the anthropogenic activities. The construction of road in unscientific manner, poor engineering design, disturbing slope stability, widening of road, changes in natural drainage network, disturbing old landslides, instability due to the machine vibrations, cutting of trees etc. are major reasons of landslide ${ }^{[3,17,18]}$. The demarcation of landslide hazard zonation along the road network will be helpful for the prevention and mitigation of any region. Landslide hazard zonation map shows probable areas of landslide occurrence and it is useful for better management and mitigation of area. The study of landslide is a most important task for scientists, engineer, planners and administrations, they spent their several time in the research of landslide potential area $[9,4]$. Various qualitative and quantitative methods and techniques have been used for the landslide hazard and susceptibility zonation mapping based on the requirement of the researcher and study area.

Remote Sensing and GIS have widely used for the demarcation of landslide hazard zones and mapping of probability of occurrence ${ }^{[11]}$. Therefore, may researcher have been use the Remote Sensing and GIS techniques for the landslide hazard studies along the road network. Gawali P. B. et al. [6] identified landslide susceptible villages around Kalsubai Region, Western Ghats of 
Maharashtra using the heuristic technique based on weighted score method. Laltlankima et al. [14] investigates the landslide hazard zones along the highway between Aizawl city and Lengpui airport of Mizoram, India using Geospatial techniques. The road was buffered $50 \mathrm{~m}$ on both side to delineate the study area. Five thematic layers viz., slope morphometry, geological structures like faults and lineaments, lithology, geomorphology and land use / land cover used for identified the landslide zonation. Nepal N. et al. ${ }^{[15]}$, analysed landslide susceptibility assessment along the Araniko highway of Nepal Himalaya, using the relationship between the landslide causative factor and presence/absence of landslide using linear discriminant analysis. Anbazhagan S. et al. [1], carried out landslide hazard zonation mapping in ghat road section of Kolli Hills, India using a landslide hazard evaluation factor (LHEF) rating scheme. They calculated LHEF rating scheme and the total estimated hazard (TEHD) as per the Bureau of Indian Standard (BIS) guidelines (IS: 14496 (Part-2) 1998). Ramesh et al. [16] examined the landslide hazard zonation mapping and cut slope stability analyses along Yercaud ghat road (Kuppanur Yercaud) section, Tamil Nadu, India, in this research they prepare macro LHZ map using the landslide hazard evaluation factor (LHEF) rating scheme proposed by Bureau of Indian Standard IS 14496 (Part-2) 1998. Chingkhei R. K. et al. ${ }^{[2]}$ prepare landslide hazard zonation in NH-1A in Kashmir, Himalaya, India, using GIS and remote sensing data. Khamkar D. J. et al. [13] investigate the mass movement in Varandha Region, Western Ghat of Maharashtra using Geospatial technique. They investigate the mass movement for prepare the map of highly vulnerable locations, in this area and the remedial measures are suggested to minimize the severity of landslide in Varandha Ghat section.

The present study focuses on the assessment of the landslide hazard zonation along $11 \mathrm{~km}$ long stretch of Kelghar ghat section of $\mathrm{MH} \mathrm{SH}-73$, in between Mahabaleshwar and Medha. This highway connects to the most popular tourist place of Mahabaleshwar. This is a first scientific study adopted for this ghat section. Fifteen thematic layers were prepared based on the data collected from different sources (Table1) for Landslide Hazard Zonation (LHZ) in the GIS environment. In the present context, detailed investigations of the landslide using geospatial technology were carried out to prepare the LHZ map of the study area will be helpful for the mitigation and remedial measures of landslide along this vibrant state highway.

\section{STUDY AREA}

The study area is located on the border of Jaoli and Mahableswar tehsil along with $\mathrm{MH} \mathrm{SH-73} \mathrm{on} \mathrm{the} \mathrm{western} \mathrm{part}$ of Satara district, Maharashtra. The $11 \mathrm{~km}$ ghat section called as Kelghar ghat and it is connected to important tourist place Mahabaleshwar from Satara and Western Maharashtra. This specific ghat section starts at the coordinates of $17^{\circ} 53^{\prime} 29.49^{\prime \prime} \mathrm{N} \&$ $73^{\circ} 42^{\prime} 45^{\prime \prime} \mathrm{E}$ and ends at $17^{\circ} 51^{\prime} 18.88^{\prime \prime} \mathrm{N} \&$ $73^{\circ} 45^{\prime} 59.33^{\prime \prime} \mathrm{E}$. Location map of the study area is shown in Fig. 1. The elevation ranges from $746 \mathrm{~m}$ at Kelghar and the maximum is $1375 \mathrm{~m}$ at Machutar above mean sea level (msl). The general elevation is increased toward the Mahabaleshwar. Geologically, this region is part of the Mahabaleshwar Poladpur formation and the area shows thick flows of the Deccan Trap basalt of Upper Cretaceous to Eocene age ${ }^{[13]}$. Therefore, the road transportation in this area are highly vulnerable to landslide disaster every year. The climate of this area is agreeable. The average annual rainfall is $5000 \mathrm{~mm}$ and highest on the top of the study area. About $87 \%$ rainfall occurs during the southwest monsoon season. The maximum and minimum temperature is $26{ }^{\circ} \mathrm{C}$ and $16.2{ }^{\circ} \mathrm{C}$ respectively ${ }^{[12]}$. Study area is the part of the Western Ghat (Sahyadri), which as biodiversity hotspot of the country. May rare, endangered flora and fauna are found in this area. 


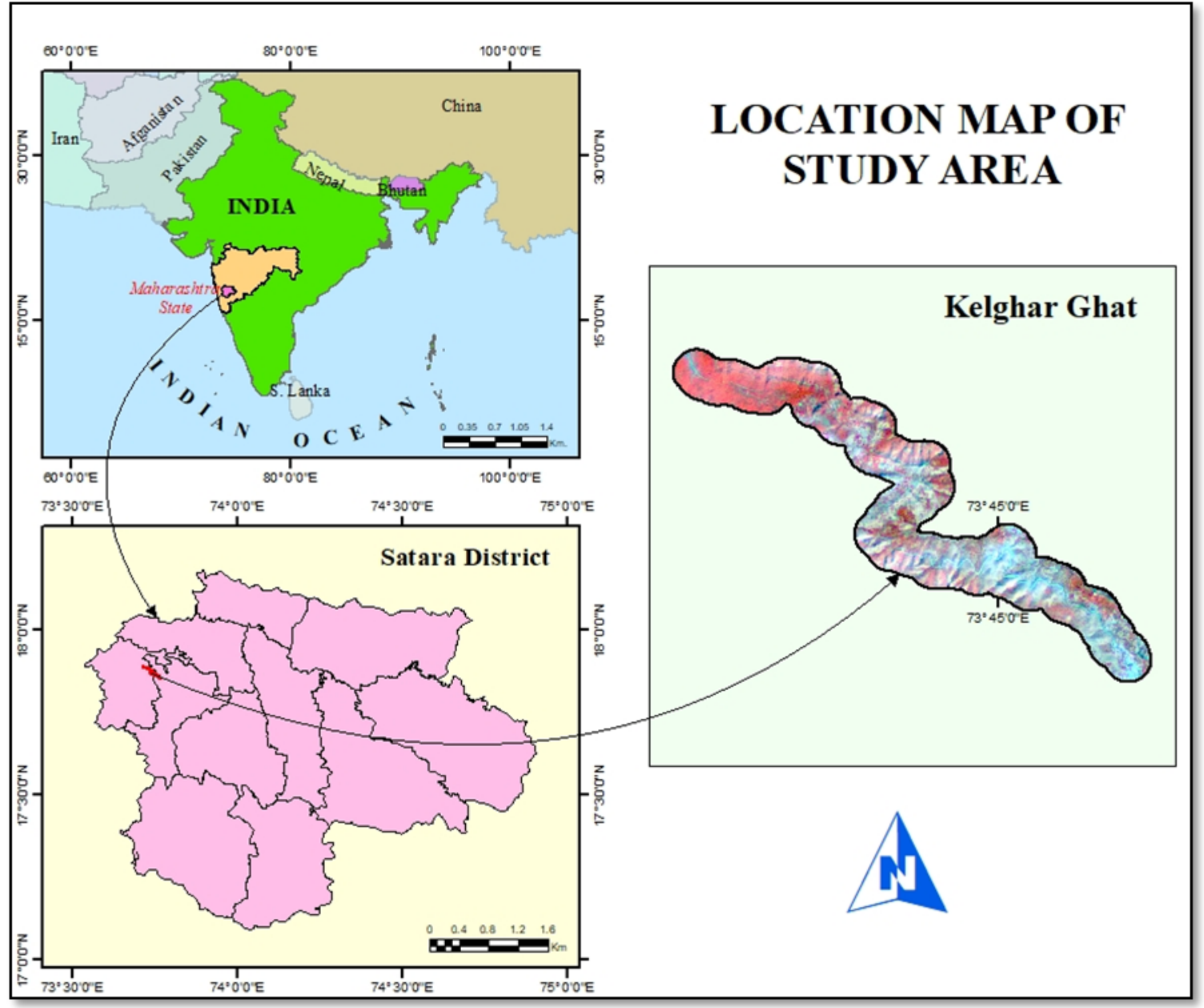

Fig. 1

\section{MATERIALS AND METHODS}

In this present study, the research work is divided into three part, Pre-field work, field work, and post field work. The flowchart of the methodology is shown in Fig. 2.

Pre-field work is carried out the review of previous literature and collection of data from different sources. Fifteen landslide triggering and causative factors selected for this study based on the review of previous literature. Like slope, rainfall, relief, lithology, soil depth, soil erosion, soil texture, land use / land cover, drainage distance, drainage density, lineament distance, lineament density, aspect and temperature were collected from various sources (Table 1).

Field work were carried out for define the extent of the study area, data validation and collection of location of past landslide. The ghat section was buffered
$100 \mathrm{~m}$ on both side to define the extent study area based on the field investigation. The past landslide inventory is the most important factor for identify the most vulnerable zone in the study area. The data of past landslide was collected using the evidences of past landslide, press coverage and local information. The past landslide locations were demarcated with help of GPS (Garmin GPS Map 78) and geotag photograph. Landslide inventory was plotted as a line feature along the ghat road section digitized from Google earth and satellite image. In the last 5 years, there are about 5 times (16 July 2017, 17 June 2018, 18 June 2020, 17 June 2021, 22 July 2021) landslide events were occurred at Kala Khadak near Varoshi village.

Post field work carried out for preparation of thematic map and LHZ map. Fifteen thematic layers were prepare in GIS platform using ArcGIS 10.5 and ERDAS 
Subhash Vishnu Karande. Landslide hazard zonation along the MH SH-73 at Kelghar Ghat, Satara, Maharashtra.

IMAGINE software. The heuristic techniques based on the local information and prior knowledge of past landslide are used for the assign the scale and weight (Table 2) for individual parameter ${ }^{[6,12]}$. The highest weight assigned to landslide inventory (20), slope (16), relief (12), lithology (12) and rainfall (08) based on their importance and triggering intensity in the landslide frequency. Final landslide hazard zonation (LHZ) map of the study area prepared by using the weight base multi-criteria overlay method in GIS domain using ArcGIS 10.5 software. Based on the score, the entire study area were divided in six zones (Fig. 2) like Very high, High, Medium, Low, Very low and No risk [12]

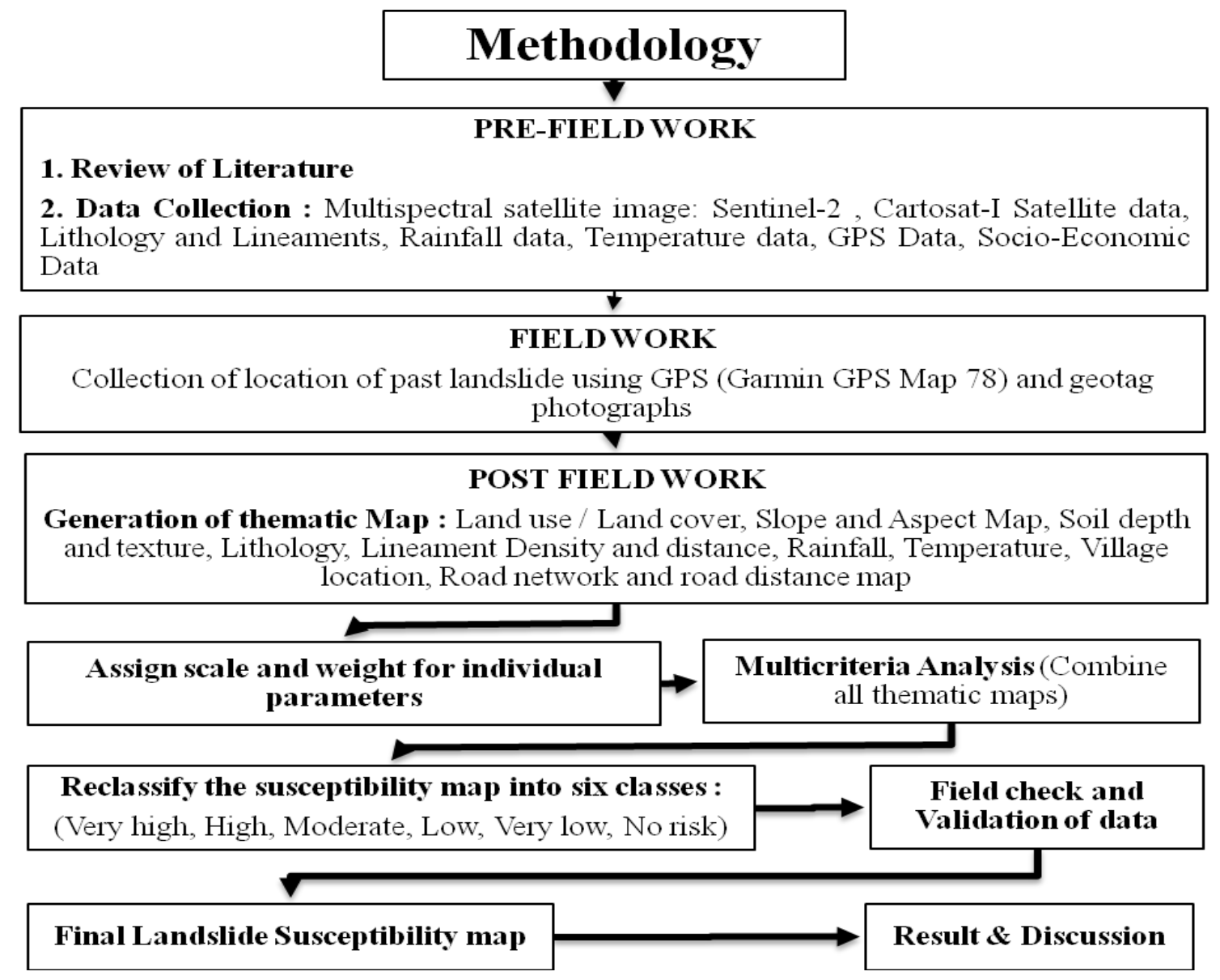

Fig. 2

Table 1: Data sources and specific use

\begin{tabular}{|l|l|l|l|}
\hline Sr. No. & Data Types & Source Hub & Data/Layer Extracted \\
\hline 1 & $\begin{array}{l}\text { Multispectral satellite image: } \\
\text { Sentinel-2 } \\
\text { Spatial resolution - 10 M }\end{array}$ & $\begin{array}{l}\text { Sentinel Data Open } \\
\text { (https:///scihub.copernicus.eu/) }\end{array}$ & Land use / Land cover \\
\hline 2 & $\begin{array}{l}\text { DEM Satellite data: Cartosat- } \\
\text { I Spatial resolution- 2.5 M }\end{array}$ & $\begin{array}{l}\text { Bhuvan } \\
\text { (https:///hhuvan-app3.nrsc.gov.in/data/download/index.php })\end{array}$ & Slope and Aspect Map \\
\hline 3 & $\begin{array}{l}\text { Soil Data } \\
\text { Scale -1: 500000 }\end{array}$ & European Soil Data Center (https://esdac.jrc.ec.europa.eu/) & Soil depth and texture map \\
\hline 4 & $\begin{array}{l}\text { Lithology and Lineaments } \\
\text { Scale - 1:50000 }\end{array}$ & $\begin{array}{l}\text { Bhukosh website } \\
\text { (http:///bhukosh.gsi.gov.in/Bhukosh/MapViewer.aspx) })\end{array}$ & $\begin{array}{l}\text { Lithology map, Lineament } \\
\text { Density and distance }\end{array}$ \\
\hline 5 & Rainfall data & $\begin{array}{l}\text { MD and Maharashtra agriculture websites } \\
\text { (http://mahaagri.gov.in/) }\end{array}$ & Rainfall data \\
\hline 6 & Temperature data & $\begin{array}{l}\text { India Meteorological Department of Pune } \\
\text { (https://imd.gov.in/) }\end{array}$ & Temperature data \\
\hline 7 & GPS Data & Field work & $\begin{array}{l}\text { Ground truthing and location } \\
\text { of past inventory }\end{array}$ \\
\hline 8 & Road Network & Google Earth Image \& Field work & $\begin{array}{l}\text { Road network and road } \\
\text { distance map }\end{array}$ \\
\hline
\end{tabular}


Subhash Vishnu Karande. Landslide hazard zonation along the MH SH-73 at Kelghar Ghat, Satara, Maharashtra.

Table 2: Allotted weightage to parameter

\begin{tabular}{|l|l|}
\hline Parameter & Weightage (\%) \\
\hline 1. Landslide Inventory & 20 \\
\hline 2. Slope & 16 \\
\hline 3. Relief & 12 \\
\hline 4. Lithology & 12 \\
\hline 5. Rainfall & 8 \\
\hline 6. Land use / Land cover & 5 \\
\hline 7. Soil depth & 4 \\
\hline 8. Drainage distance & 4 \\
\hline
\end{tabular}

\begin{tabular}{|l|l|}
\hline Parameter & Weightage (\%) \\
\hline 9. Drainage density & 4 \\
\hline 10. Soil texture & 4 \\
\hline 11. Lineament distance & 3 \\
\hline 12. Lineament density & 3 \\
\hline 13. Soil erosion & 3 \\
\hline 14. Aspect & 2 \\
\hline 15. Temperature & 2 \\
\hline Total & 100 \\
\hline
\end{tabular}

\section{RESULTS AND DISCUSSION}

The highway is lifeline of the development of any area. Rainfall is most triggering factor of landslide in Western ghat and every year frequent occurrence of landslide in the ghat section causes loss of lives and property. Study of the landslide probable zone can reduced the loss of lives and property along road network. The study incorporated predefined important landslide causative factors, viz. slope, rainfall, relief, lithology, soil depth, soil erosion, soil texture, land use / land cover, drainage distance, drainage density, lineament distance, lineament density, aspect, temperature, and landslide inventory (Table 1) and in this approach fifteen thematic layers were prepared using GIS platform.

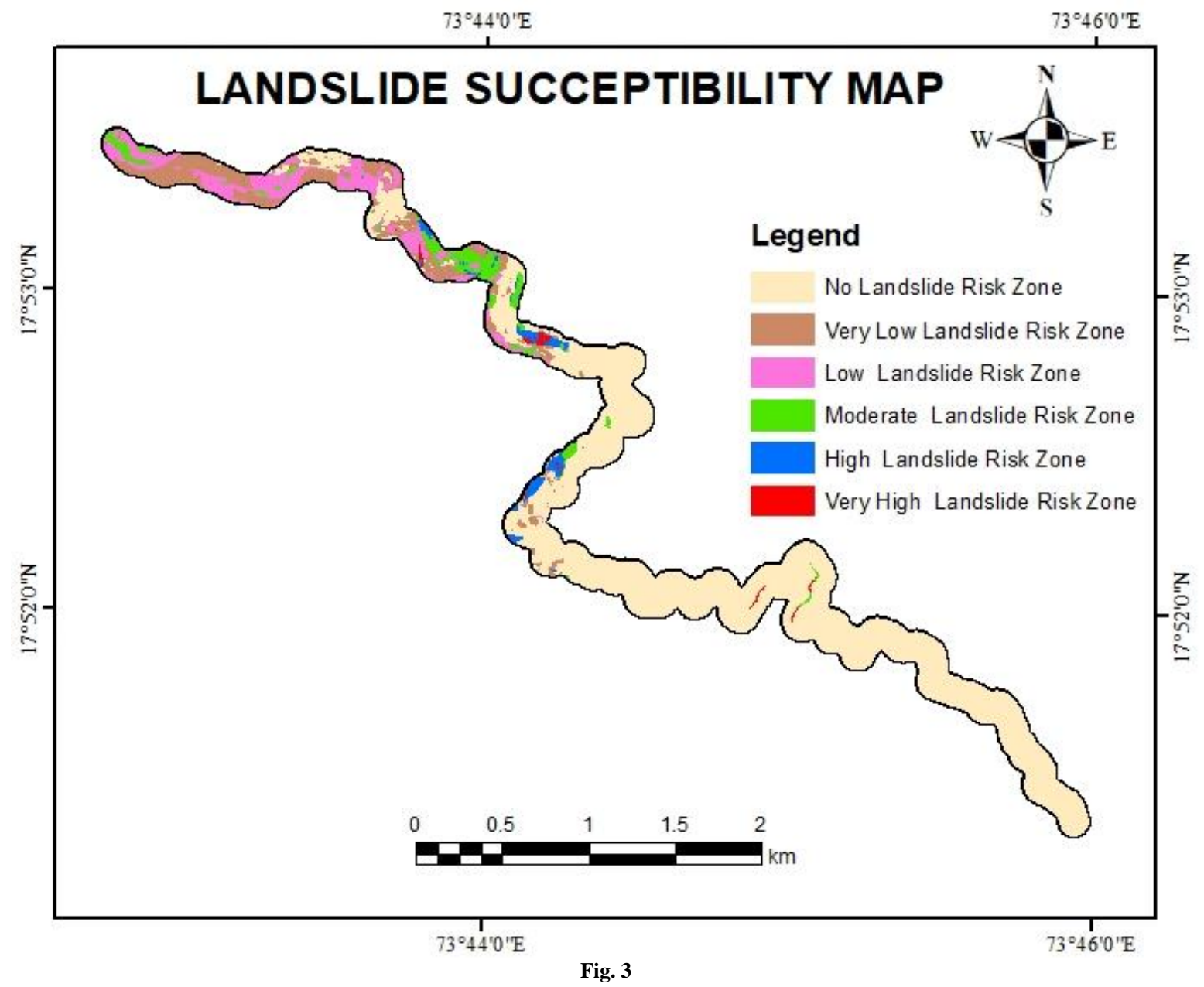

In this study, based on assign weight and score for individual parameter the landslide hazard zonation map was prepared in ArcGIS 10.5 and Kelghar ghat has been categorized into six classes: Very high,
High, Medium, Low, Very low and No risk, Final landslide hazard zonation map is shown in Fig. 3. Very high and high hazard zones indicating the area is relative unstable, whereas the moderate, low and 
very low hazard zones indicating moderate to low instability of the area. No risk zones indicating stable area without any vulnerability and it are safe for human activity. The landslide hazard zonation map shows very high risk zone is about 1.3 percent $(0.1 \mathrm{Sq}$. Km.) of the total area, which depicts steep slopes more than $35^{\circ}$, where higher weathering, slope cut for road construction and limited forest cover. Most of the time past landslides are observed in this zone. There required immediate action plan for management and mitigation of this zone. High hazard zone is also vulnerable to landslide activity, 1.7 percent $(0.2 \mathrm{Sq}$. $\mathrm{Km}$.) area of this study region are under this zone. Slope above $25^{\circ}$, high weathering, fractured and displaced in the rock were most triggering factors in this zone. Moderate zone is generally more stable as compared to the above two zone. This zone covered 3.4 percent $(0.3 \mathrm{Sq}$. Km.) area of ghat section. Very limited past landslide incidence were observed in this zone. Most of the hotel and human settlement were situated in this zone. It is recommended that avoid landslide triggering activity in this zone to maintain its present status. Low and very low hazard zone is located on the left side of ghat section. It occupied 7.6 percent (0.7 Sq. Km.) and 8.4 percent (0.8 Sq. Km.) of the study area (Fig. 1), respectively. The slope angel more than $25^{\circ}$ is most crucial factor in these zones. It is relatively stable and safe for human activity, like hotels and settlement. 77.7 percent (7.2 Sq. Km) area under the no risk zone. No any past landslide inventory were observed in this area and this is stable and safe for human activity.

\section{CONCLUSION}

Landslide is more frequent phenomena were observed along the road networks of the Western Ghat, during rainy season. The construction of road in the mountain area in unscientific manner, poor engineering design, disturbing slope stability, widening of road, changes in natural drainage network, disturbing old landslides, instability due to the machine vibrations, cutting of trees etc. are just some of these reasons. Kelghar ghat faces frequent landslides every year during monsoon and its causes road jam, loss of property, damage of road constructions but no major incidence were observed in this section. Fifteen thematic layers were prepared based on the data collected from different sources for Landslide Hazard Zonation (LHZ) in the GIS environment. Heuristic techniques based on the local information and prior knowledge of past landslide use for preparation LHZ map. LHZ mapping of this study area using fifteen thematic layers was done using heuristic techniques based on the local information and prior knowledge of past landslide. Finally, LHZ map was divided into six zones i.e Very high, High, Medium, Low, Very low and No risk and it is covering with $1.3 \%, 1.7 \%, 3.4 \%, 7.6 \%$, $8.4 \%$ and $77.7 \%$, part of the study area respectively. Very high and high vulnerable areas were found near Varoshi Village, where slope is above $25^{\circ}$. Barren land and slope cutting for road construction in the ghat section were more vulnerable and large numbers of landslide were observed in this area. No any landslides were observed in the dense forest area during field visit.

This study is conducted first time in this ghat section. There are urgent need for mitigation measure like slope stability, plantation and reforestation, drainage correction, CCT over the high elevated area, removal of loose boulders, geosynthetic net, warning flex and board etc. The demarcated landslide vulnerability zone of this ghat section will be more helpful to engineers, planners and administrator for the construction activities, mitigation and remedies for reduce the loss of lives and property.

\section{ACKNOWLEDGEMENT}

The author is grateful to the Impactful Policy Research in Social Science (IMPRESS) of ICSSR, New Delhi and The Ministry of Human Resource Development 
(MHRD) for financial assistance. The author is also grateful to the Chhatrapati Shivaji College, Satara for the research facility for this research.

\section{Conflict of Interest: None}

\section{Source of Funding: None}

\section{REFERENCES}

1. Anbazhagan S. and Ramesh V., (2014): Landslide hazard zonation mapping in Ghat Road section of Kolli Hills, India, Journal of Mountain Science, Vol:11(5), pp. 13081325

2. Chingkhei R. K., Shiroyleima A., Robert Singh L. and Kumar A., (2013): Landslide Hazard Zonation in NH-1A in Kashmir, Himalaya, India, International Journal of Geosciences, Vol: 4, pp. 1501-1508

3. Das I. C., Stein A., Kerle N. and Dadhwal V. K., (2011): Probabilistic landslide hazard assessment using homogeneous susceptible units (HSU) along a national highway corridor in the northern Himalayas, India. Landslides, Vol:8, pp. 293-308. DOI: 10.1007/ s10346-011-0257-9.

4. Devoli G., Morales A. and Hoeg K. (2007) Historical landslides in Nicaragua collection and analysis of data. Landslides, Vol:4(1), pp. 5-18. DOI: 10.1007/s10346006-0048-x.

5. Fassin D. and Vasquez P., (2005): Humanitarian Exception as the Rule: The Political Theology of the 1999 Tragedia in Venezuela. Vol. 32, pp.389 - 405.

6. Gawali P. B., Aher S. P., Lakshmi B.V., Gaikwad R. D., Deendayalan K., Hanamgond P. T., Mahesh Babu J.L.V., Arote S. A., and Bairagi S. A., (2017): Identification of Landslide Susceptible Villages around Kalsubai Region, Western Ghats of Maharashtra using Geospatial Techniques, Journal Geological Society Of India Vol: 90, pp.301-311

7. Glade T., (2003): Landslide occurrence as a response to land use change: a review of evidence from New Zealand. Catena, Vol:51(3), pp.297-314.

8. Goetz J. N, Guthrie R.H, Brenning A. (2011): Integrating physical and empirical landslide susceptibility models using generalized additive models.
Geomorphology, Vol: 129(3-4), pp. 376 86.

9. Guzzetti F., Galli M., Carrara A., Cardinalli M. and Reichenbach P., (1999): Landslide hazard evaluation: a review of current techniques and their application in a multiscale study, Central Italy, Geomorphology, Vol: 31 (1- 4), pp. 181-216. http://dx.doi.org/10.1016/S0169555X(99)00078-1

10. Hayati E., Majnounian B., Abdi E., Sessions J. and Makhdoum M., (2013):An expertbased approach to forest road network planning by combining Delphi and spatial multi-criteria evaluation. Environmental Monitoring \& Assessment, Vol: 185(2), pp. 1767-1776.

11. Jeganathan C. and Chauniyal D.D., (2000): An evidential weighted approach for landslide hazard zonation from geoenvironmental characterization: A case study of Kelani area. Current Science, Vol: 79(2), pp. 238-243.

12. Karande S.V., (2021): Landslide Susceptibility Mapping in Mahabaleshwar Tehsil, Satara, Maharashtra using Geospatial Technology. Journal of Science and Technology, Vol: 6 (4), DOI: https://doi.org/10.46243/jst.2021.v6.i04.pp1 88-194

13. Khamkar D. J., Mhaske S. Y., (2018): Investigation of the mass movement in Varandha Region, Western Ghat of Maharashtra using Geospatial Technique, International Journal of Civil Engineering and Technology, Vol: 9(7), pp. 2011-2027,

14. Laltlankima, Lalbiakmawia F., (2016) : Landslide hazard zonation along National Highway between Aizawl City and Lengpui Airport, Mizoram, India using Geospatial Techniques, International Journal of Engineering Sciences \& Research Technology, Vol:5(7), pp1024-1033.

15. Nepal N., Chen J., Chen H., Wang X. and Sharma T.P., (2019) : Assessment of landslide susceptibility along the Araniko Highway in Poiqu/ Bhote Koshi/Sun Koshi Watershed, Nepal Himalaya, Progress in Disaster Science, Vol: 3 (100037), pp.1-8.

16. Ramesh V., Mani S., Baskar M., Kavitha G., and Anbazhagan S., (2017): Landslide hazard zonation mapping and cut slope stability analyses along Yercaud ghat road (Kuppanur -Yercaud) section, Tamil Nadu, 
Subhash Vishnu Karande. Landslide hazard zonation along the MH SH-73 at Kelghar Ghat, Satara, Maharashtra.

India, International Journal of GeoEngineering Vol:8(2) pp.1-22.

17. Sidle R.C, Ziegler A. D., Negishi J. N., Nik A. R., Siew R. and Turkelboome F., (2006): Erosion processes in steep terrain - Truths, myths, and uncertainties related to forest management in Southeast Asia, Forest Ecology and Management, Vol:224 (1-2), pp.199-225.

https://doi.org/10.1016/j.foreco.2005.12.019
18. Sidle R.C. and Ochiai H. (2006): Landslides: Processes, Prediction, and Land Use, Vol: 18, DOI:10.1029/WM018

How to cite this article: Karande SV. Landslide hazard zonation along the MH SH-73 at Kelghar ghat, Satara, Maharashtra. International Journal of Research and Review. 2021; 8(9): 540-547. DOI: https://doi.org/10.52403/ijrr.20210968 